\title{
Evaluation of Comparative Immunomodulatory Potential of Solanum xanthocarpum Root and Fruits on Experimental Animal
}

\author{
Ravindra Kumar Pandey,1,2, Shiv Shankar Shukla², Anurekha Jain², Avijeet Jain², Vipin Bihari Gupta², \\ Lokesh Deb \\ ${ }^{1}$ Columbia Institute of Pharmacy, Raipur-492001, Chhattisgarh, INDIA. \\ ${ }^{2}$ BRNSS-Contract Research Center, B. R. Nahata College of Pharmacy, Mandsaur-458001 Madhya Pradesh, INDIA. \\ ${ }^{3}$ Institute of Bio resources and Sustainable Development (An autonomous Institute of Department of Biotechnology, Government of \\ India) - Sikkim Centre (IBSD-SC), 5th mile, NH-10A, Near Metro Point, Tadong, Gangtok -737102, Sikkim, INDIA.
}

\begin{abstract}
Aim: This study was aimed to justify the scientific basis in folklore use of Solanum xanthocarpum (solanaceae) as an Immunomodulatory agent in India. Materials and Methods: The ethanol and aqueous extracts of $S$. xanthocarpum fruit (SXE-1 and SXA-1), root (SXE-2 and SXA-2) and whole plant (SXE-3 and SXA-3) were evaluated for immunomodulatory activity by using cold water swim endurance stress test, delayed type hyper sensitivity reaction, carbon clearance test and $\mathrm{CCl}_{4}$ induced oxidative stress model on experimental animals. The solasodaine content in $S$. xanthocarpum bioactive test samples were quantified by HPLC to establish phyto-pharmacological relationship. Results: The $200 \mathrm{mg} / \mathrm{kg} /$ day p.o. dose of test samples were showed significant changes in swimming survival time and at same doses test samples were significantly increased hypersensitivity, decrease in carbon clearance and reduced oxidative stress. Where, SXE-1 and SXA-1 exhibited maximum degree of immunomodulatory effect compared to SXE-2, SXA-2, SXE-3, SXA-3 and respective standard drugs used in this study. The hematological, biochemical and histopathological studies were supported respective results of the test samples. The solasodaine content in SXA-1 $(1.146 \%)$, SXE-1 $(0.894 \%)$, SXE-2 $(0.643 \%)$ and SXA-2 $(0.620 \%)$ were estimated by HPLC. Conclusion: These observations established the traditional claim and thus $S$. xanthocarpum could be a potent immunomodulatory agent for use in near future. The immunostimolatory effect may be due to presence of solasodaine in $S$. xanthocarpum extracts.
\end{abstract}

Key words: $S$. xanthocarpum, Solasodaine, HPLC, Immunomodulatory, $\mathrm{CCl}_{4}$.

\section{INTRODUCTION}

The body immune system is involved in the etiologic and pathophysiologic mechanisms of many human diseases. Therefore, Immunomodulation may be served as useful target for control of those human diseases. ${ }^{1}$ The natural resistance of the body against infection can be enhanced by the use of herbal drugs. ${ }^{2}$ Medicinal plants are rich sources of bioactive phytochemicals that enhance immunity, the non-specific immunomodulation of essentially granulocytes, macrophages, natural killer cells other complement factors. ${ }^{1}$ With this background, it was planned to explore the immunomdulatory effect of locally available plant used in folklore health care system for related disorders. Based on consultation of literature survey, Solanum xanthocarpum Schrad and Wendl species was selected that are commonly used in the region for the autoimmune disease.

Solanum xanthocarpum Schrad and Wendl (Solanaceae) commonly known as Yellow Berried Nightshade (syn: kantakari), is a
Submission Date: 15-03-2018; Revision Date: 20-06-2018; Accepted Date: 14-08-2018

DOI: 10.5530/ijper.52.4s.103 Correspondence:

Mr. Lokesh Deb, Institute of Bioresources and Sustainable Development (IBSD) - Sikkim Centre, (Department of Biotechnology, Government of India), 5th mile, NH-10A, Near Metro Point, Tadong, Gangtok -737102, Sikkim, INDIA.

Phone: +91-9436890969 E-mail: lokeshdeb@gmail. com

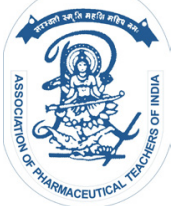

www.ijper.org 
prickly diffuse bright green perennial herb, woody at the base, $2-3 \mathrm{~m}$ height found throughout India, mostly in dry places as a weed on road sides and waste lands. ${ }^{3}$ The Mukundara tribals of Rajasthan used for treatment of hernia. ${ }^{4}$ Local peoples of Taindol village, district Jhansi, Uttar Pradesh used for treatment of Asthma, Bronchitis, Cardio tonic, Chest pain, Cough, Diuretic, Fever, Gonorrhoea, Jaundice, Skin diseases, Toothache, Tuberculosis, Ulcers. ${ }^{5}$ In Manipur, fruits are consumed as vegetable and local healers of Manipur are also used for treatment of various diseases. ${ }^{6}$ In ancient Ayurveda, mentioned uses of the plant as pungent, bitter tonic, digestive, alternative astringent. The stem, flower, fruits have used as bitter tonic and carminative. Roots decoction used as ferifuge, diuretic and expectorant. Charaka and Sushruta used the extracts of whole plant and fruits oraly for treatment of bronchial asthma, tympanitis, misperistalsis, piles, rejuvenation and dysuria. The 'Kantkari Ghrita' of Charaka is specific formulation for cough and asthma. ${ }^{7}$ The fruits are known for several medicinal uses like anthelmintic, antipyretic, laxative, antiinflammatory, anti-asthmatic and aphrodisiac activities. ${ }^{8}$ The stem, flowers and fruits are prescribed for relief in burning sensation in the feet accompanied by vesicular eruptions.' The hot aqueous extract of dried fruits used for treating cough, fever, and heart diseases. ${ }^{10}$ The fruit paste is applied externally to the affected area for treating pimples and swellings. ${ }^{11}$ Traditionally, the juice of the leaves is used for treatment of rheumatism, an autoimmune disorder, ${ }^{12}$ and fruit juice is useful in sore throat and rheumatism..$^{13}$ the decoction of the of the fruit is used by traditional healers of Jharkhand and Orissa for the the treatment of diabetes. The different bioactive phytochemical including solasodine (steroidal alkaloid), tomatidenol (alkaloid), alpha-Solamargine (alkaloid), diosgenin (sapogenin), Apigenin (flavonoid), beta-sitosterol (steroid), linoleic acid (fatty acid), lupeol (triterpenoid) etc were reported to be present in $S$. xanthocarpum plant. $^{6}$

The present investigation was aimed to justify the pharmacological basis of traditional use of $S$. xanthocarpum as immunomodulatory agent and to explore the bioactive component(s) which effect in physiological mechanism that caused immunomodulation.

\section{MATERIALS AND METHODS}

\section{Plant material and extraction procedure}

Fruit, root and whole plant including leaves, roots, roots and stems of $S$. xanthocarpum were collected from the surrounding fields of Mandsaur, Madhya Pradesh, India in the month of August and identified at Department of Botany, Govt. P. G. College, and Mandsaur, India. A voucher specimen (SX/002/2005/BRNCOP) has been deposited for future reference. Shade dried coarse powdered (10\#) fruit, root and whole plant were defatted with petroleum ether, and extracted with $95 \%$ ethanol by soxhlation method (SXE-1, SXE-2 and SXE-3 respectively) and aqueous extracts obtained by occasional shaking of powdered fruit, root and whole plant with distilled water (SXA-1, SXA-2 and SXA-3 respectively).

\section{Phytochemical screening}

Preliminary phytochemical screening of extracts was carried out for the presence of phyto-constituents like alkaloids, flavonoids, steroids and saponins. ${ }^{14}$

\section{Experimental Animals}

Wistar albino rats (150-200 gm) of either sex obtained from Institutional Animal House of B.R. Nahata College of Pharmacy, Mandsaur for the study. Animals were maintained under normal environmental condition: (Room temperature $-27 \pm 3{ }^{\circ} \mathrm{C}$, Relative humidity $65 \pm 10 \%, 12 \mathrm{~h}$ light / dark cycle). The animals were fed with standard diet and water was given ad libitum under strict hygienic conditions. The permission of Institutional animal ethical committee was obtained before starting the experiments (approved proposal No. (34/M.Ph/06/IAEC/BRNCOP). All Experiments were performed in accordance with the current guidelines of CPCSEA, Government of India.

\section{Acute Toxicity Study $\left(\boldsymbol{A L D}_{50}\right)$}

The acute toxicity of the tested extracts was determined in Wistar albino rats, maintained under standard conditions. The animals ( 3 animals in a group) were fasted overnight prior to the experiment. Acute oral toxicity - acute toxic class method (OECD Guideline no. 423, Annexure - 2d) adopted by CPCSEA, Government of India was followed for toxicity studies. The mortality was observed after oral administration of $2000 \mathrm{mg} / \mathrm{kg} \mathrm{b}$. w test samples SXE-1, SXA-1, SXE-2 and SXA-2. ${ }^{15}$ Common side effects such as, mild diarrhoea and depression of treated groups of animals were recorded within the $72 \mathrm{~h}$.

\section{Cold water swim endurance stress test}

Cold water swim stress test was performed according to Bhargava and Singh (1981) with some modifications. ${ }^{16}$ The wistar albino rats were segregated into seven groups $(n=6)$. Group I served as normal control, group II was stress control and received only purified water $(10 \mathrm{ml} / \mathrm{kg} /$ day). Group III was treated with ashwagandha capsule, (Himalaya Drug Co. India) at dose of $50 \mathrm{mg} / \mathrm{kg} /$ day p.o. as standard drug. Group IV-VII was 
administered with the tested extract SXE-1, SXA-1, SXE-2 and SXA-2 respectively at a dose of $200 \mathrm{mg} / \mathrm{kg} /$ day p.o. The animals of Group II-VII were allowed to swim till exhausted after 45 min of the treatment. The mean swimming time on $7^{\text {th }}$ day for each group was calculated. On the $8^{\text {th }}$ day, animals were individually placed in plastic container of capacity $400 \mathrm{ml}$ and animals were immobilized in normal position, using adhesive tape. The container was placed in a refrigerator for $2 \mathrm{~h}$. The blood was collected by heart puncture method for estimation of hematological studies like WBC count, differential leucocytes counts, ${ }^{17}$ blood glucose, cholesterol and triglycerides (using commercially available kits from Span Diagnostics Pvt. Ltd, India).

\section{Delayed type hypersensitivity}

The delayed type hypersensitivity was induced according to the reported method of Agarwal et al. 1999 with some modifications using rabbit red blood cells (RRBC) as an antigen. The animals were divided into six groups of six animals each. Group I served as control (saline water, $10 \mathrm{ml} / \mathrm{kg} /$ day). Group II animals were administered levamisole $25 \mathrm{mg} \mathrm{kg}^{-1}$ orally as standard drug and group III -VI was administered with the test samples SXE-1, SXA-1, SXE-2 and SXA-2 respectively at a dose of $200 \mathrm{mg} / \mathrm{kg} /$ day p.o. for 5 days. On $5^{\text {th }}$ day, $45 \mathrm{~min}$ latter of the treatment, the animals were challenged with $1 \times 10^{5}$ (RRBC) subcutaneously in the hind paw. The right hind paw received saline only. Paw volume was measured with the help of plethysmograph on $1 \mathrm{~h}, 24 \mathrm{~h}$ and $48 \mathrm{~h}$ after the challenge. The difference in paw volume was taken as measure of delayed hypersensitivity (DHS). ${ }^{18}$

\section{Carbon clearance test}

In-vivo immunomodulation study, the change in macrophages (Phagocytic activity), was determined by using carbon clearance assay on albino rats according to the reported method of Ponkshe and Indap (2002) with some modifications. The animals were divided into six groups of six animals each. Group I (control group) received $10 \mathrm{ml} / \mathrm{kg}$ body weight/p.o.), Group II were given Cyclophosphamide (50 mg/kg b.w. i.p for 3 days starting from day 4) as standard drug and Group III- VI received the $z$ test samples SXE-1, SXA-1, SXE-2 and SXA-2 respectively at a dose of $200 \mathrm{mg} / \mathrm{kg} /$ day p.o. for 7 days. On $7^{\text {th }}$ day of experiment, animals of the entire groups injected with $0.1 \mathrm{ml}$ Indian ink dispersion $(1 \mathrm{mg} / \mathrm{ml})$ intravenously through the tail vein. The blood samples $(50 \mu \mathrm{l})$ were withdrawn from tail vein after 5,10 , 15 and 30 min after Indian ink injection (mean time is reported in Table 6). The individual aliquot was lysed with $2 \mathrm{ml}$ of $1 \%$ acetic acid and absorbance was measured calorimetrically at $660 \mathrm{~nm}$. Rate of carbon clearance $(\mathrm{K})$ and phagocytic index $(\alpha)$ were calculated. ${ }^{19}$

\section{$\mathrm{CCl}_{4}$ induced oxidative stress}

The animals were divided into five groups of six animals each. Group I served as normal control and received saline water $(1 \mathrm{ml} / \mathrm{kg}$, p.o.) daily for 5 days and received olive oil ( $1 \mathrm{ml} / \mathrm{kg}$, S.C.) on days 2 and 3 . Group II served as $\mathrm{CCl}_{4}$ control and received distilled water $(1 \mathrm{ml} / \mathrm{kg}$, p.o. $)$ daily for 5 days and received $\mathrm{CCl}_{4}$ : olive oil $(1: 1,2 \mathrm{ml} / \mathrm{kg}$, S.C.) on days 2 and 3. Group III was treated with the reference drug silymarin ( $50 \mathrm{mg} / \mathrm{kg}$, p.o.) daily for 5 days and received $\mathrm{CCl}_{4}$ : olive oil $(1: 1,2 \mathrm{ml} / \mathrm{kg}$, S.C.) on days 2 and 3, 30 min after administration of reference drug. Groups IV and V were treated with SXE -1 and SXA $-1200 \mathrm{mg} / \mathrm{kg}$ p.o., respectively (as SXE-1 and SXA-1 exhibited maximum degree of immunostimulation in above stated bioassays), for 5 days and received $\mathrm{CCl}_{4}$ : olive oil (1:1, $2 \mathrm{ml} / \mathrm{kg}$, S.C.) on days 2 and 3, $30 \mathrm{~min}$ after administration of extract. The animals were sacrificed on day $6^{\text {th }}$ by cervical decapitation and blood was collected in centrifuge tubes. The serum was obtained by centrifugation. Biochemical parameters i.e. serum alkaline phosphate, SGOT, SGPT, bilirubin, ${ }^{20}$ cholesterol and HDL (using kits from Span Diagnostics Ltd) were evaluated. In histopathological study the liver tissues were dissected out and fixed in 10\% formalin. The paraffin sections were prepared and stained with haematoxylin and eosin and examined using light microscopy. ${ }^{21}$

\section{HPLC fingerprinting method of solasodine in $S$. xanthocarpum extract}

Experiments were performed on a HPLC system Shimadzu-10AT $\mathrm{T}_{\mathrm{VP}}$, binary gradient equipped with detector Shimadzu UV -VIS SPD-10 A , software Spinchrom, Chennai. The separations were performed on Merck's column [Lichrospher 100, C-18 $(250 \times 4.6 \mathrm{~mm})$ and ODS RP-18 (250 x $4.6 \mathrm{~mm}, 5 \mu$ particle size)] using methanol: acetonitrile (70:30) mobile phase with flow rate $1.0 \mathrm{ml}$ min-1.the wave length of detection was $254 \mathrm{~nm}$.

Serial dilutions containing $2-20 \mu \mathrm{g} / \mathrm{ml}$ reference solasodine in methanol were prepared from a stock solution of pure solasodine $(10 \mathrm{mg} / 100 \mathrm{ml})$. Retention time of solasodine was observed to be $3.0667 \mathrm{~min}$. The intercept and the slope of the standard plot were observed to be 53.14 and 121.1, respectively, with coefficient of correlation as $0.9935\left(\mathrm{R}^{2}\right)$. 


\section{RESULTS}

\section{Phytochemical screening}

Preliminary phytochemical screening of all the tested extracts has shown presence of alkaloids, flavonoids, steroids and saponins (Table 1).

\section{Acute Toxicity Study $\left(\boldsymbol{A L D}_{50}\right)$}

In acute toxicity study of SXE-1, SXA-1, SXE-2 and SXA-2 does not showed mortality at the dose level of $2000 \mathrm{mg} / \mathrm{kg}$. Therefore, $2000 \mathrm{mg} / \mathrm{kg}$ dose was considered as $\mathrm{ALD}_{50}$ cut off the dose under GHS 5 (safe dose), as per Globally Harmonised Classification System (GHS) for Chemical Substances and Mixtures described in OECD guideline 423(Annexure 2d). Common side effects such as, mild diarrhea and depression in treated group of animals were not recorded within the $72 \mathrm{~h}$ of observation. So, in present study, $200 \mathrm{mg} / \mathrm{kg}$ body weight $\left(1 / 10^{\text {th }}\right.$ of $\left.\mathrm{ALD}_{50}\right)$ dose was selected for in-vivo immunomodulatory study.

\begin{tabular}{|c|c|c|c|c|}
\hline Extracts & Alkaloids & Flavonoids & Steroids & Saponins \\
\hline $\begin{array}{c}\text { Ethanol extract of } \\
\text { fruit (SXE-1) }\end{array}$ & Present & Present & Present & Present \\
\hline $\begin{array}{l}\text { Aqueous extract } \\
\text { of fruit (SXA-1) }\end{array}$ & Present & Present & Present & Present \\
\hline $\begin{array}{c}\text { Ethanol extract of } \\
\text { root (SXE-2) }\end{array}$ & Present & Present & Present & Present \\
\hline $\begin{array}{l}\text { Aqueous extract } \\
\text { of root (SXA-2) }\end{array}$ & Present & Present & Present & Present \\
\hline $\begin{array}{c}\text { Ethanol extract } \\
\text { of whole plant } \\
\text { (SXE-3) }\end{array}$ & Present & Present & Present & Present \\
\hline $\begin{array}{l}\text { Aqueous extract } \\
\text { of whole plant } \\
\text { (SXA-3) }\end{array}$ & Present & Present & Present & Present \\
\hline
\end{tabular}

\section{Cold water swim stress test}

Animals administrated with test samples SXE-1 and SXA-1 have significantly $(p<0.001)$ enhanced in swimming survival time as compare to stress control group. Whereas, the samples SXE-2 and SXA-2 were significantly $(p<0.01)$ reduced swimming survival times (Table 2A). However, SXE-1, SXA-1, SXE-2 and SXA-2 Significantly reduced the elevated hematological parameters (Table 2B) and biochemical parameters (Table 2C). Results revealed fruit extracts have immunostimulant activity as compare to root extracts. Results of fruit extracts of Solanum xanthocarpum are better than the standard.

\section{Delayed type hypersensitivity}

SXE-1 and SXA-1 increased paw volume $61.25 \%$ and $63.15 \%$ respectively at $24 \mathrm{~h}$ when compared to paw volume at $1 \mathrm{~h}$, which was greater than control animals. SXE-2 and SXA-2 maximum percent $(20.0 \%$ and

\begin{tabular}{|c|c|c|}
\hline \multicolumn{3}{|c|}{ Table 2A: Effect of the tested extracts in cold stress } \\
swim test.
\end{tabular}

All values are expressed in mean \pm SEM .

$* * p<0.01$ and $* * * p<0.001$ test group vs. stress group.

\begin{tabular}{|c|c|c|c|c|c|}
\hline \multirow[b]{2}{*}{ Groups } & \multirow{2}{*}{$\begin{array}{l}\text { WBC count (No. of } \\
\text { cells } / \mathrm{mm}^{3}\end{array}$} & \multicolumn{4}{|c|}{ Differantial leucocytes count } \\
\hline & & Polymorphs & Lymphocytes & Eosinophils & Monocytes \\
\hline Control & $4636.55 \pm 66.71$ & $28.91 \pm 0.37$ & $64.05 \pm 0.41$ & $3.10 \pm 0.28$ & $0.66 \pm 0.3$ \\
\hline Stress control & $12148.00 \pm 360.84$ & $54.68 \pm 0.37$ & $96.85 \pm 0.32$ & $6.28 \pm 0.28$ & $3.04 \pm 0.31$ \\
\hline Withania somnifera & $7141.65 \pm 94.03^{* * *}$ & $40.70 \pm 1.16^{\star * *}$ & $74.17 \pm 1.96^{\star * *}$ & $5.71 \pm 0.18^{* *}$ & $2.13 \pm 0.25^{* *}$ \\
\hline SXE-1 & $8419.40 \pm 44.54^{* * *}$ & $45.12 \pm 1.03^{* * *}$ & $80.63 \pm 0.83^{* * *}$ & $5.95 \pm 0.07^{* *}$ & $2.60 \pm 0.25^{* *}$ \\
\hline SXA-1 & $6441.80 \pm 90.08^{* * *}$ & $35.58 \pm 0.61^{* * *}$ & $66.92 \pm 2.27^{* * *}$ & $5.46 \pm 0.12^{* *}$ & $1.93 \pm 0.14^{* *}$ \\
\hline SXE-2 & $10879.41 \pm 327.22^{*}$ & $56.29 \pm 0.31^{* * *}$ & $96.12 \pm 0.56^{* * *}$ & $6.91 \pm 0.56^{\star * *}$ & $3.48 \pm 0.56^{\star * *}$ \\
\hline SXA-2 & $10287.56 \pm 297.21^{*}$ & $54.27 \pm 0.39^{* * *}$ & $94.56 \pm 0.43^{* * *}$ & $6.79 \pm 0.56^{* * *}$ & $3.34 \pm 0.46^{* * *}$ \\
\hline SXE-3 & $10012.42 \pm 334.33^{*}$ & $52.34 \pm 0.41^{* * *}$ & $92.62 \pm 0.51^{* * *}$ & $6.72 \pm 0.62^{* * *}$ & $3.30 \pm 0.41^{* * *}$ \\
\hline SXA-3 & $8912.62 \pm 343.25^{\star *}$ & $46.12 \pm 0.43^{* * *}$ & $82.61 \pm 0.83^{* * *}$ & $5.97 \pm 0.07^{* * *}$ & $2.69 \pm 0.36^{* * *}$ \\
\hline
\end{tabular}

All values are expressed in mean \pm SEM,

${ }^{*} p<0.05$, ${ }^{* *} p<0.01$ and $* * * p<0.001$ test group vs. stress group. 


\begin{tabular}{|c|c|c|c|c|}
\hline \multicolumn{6}{|c|}{ Table 2C: Effect of the tested extracts on biochemical parameters and organ weight in stress swim stress test. } \\
\hline Groups & $\begin{array}{c}\text { Glucose } \\
\mathbf{m g} / \mathrm{dl}\end{array}$ & $\begin{array}{c}\text { Cholesterol } \\
\mathbf{m g} / \mathrm{dl}\end{array}$ & $\begin{array}{c}\text { Triglyceride } \\
\text { mg/dl }\end{array}$ & $\begin{array}{c}\text { Organ weight ( Liver) } \\
\text { gm / 100 gm body weight. }\end{array}$ \\
\hline Control & $84.791 \pm 1.399$ & $44.316 \pm 1.058$ & $70.88 \pm 0.7711$ & $4.34 \pm 0.107$ \\
\hline Stress control & $115.72 \pm 7.12$ & $97.16 \pm 4.21$ & $126.101 \pm 1.88$ & $7.02 \pm 0.123$ \\
\hline Standard & $89.5 \pm 6.2^{* * *}$ & $66.31 \pm 4.33^{* * *}$ & $105.31 \pm 1.19^{* * *}$ & $5.89 \pm 0.19^{* * *}$ \\
\hline SXE-1 & $49.46 \pm 3.15^{* * *}$ & $63.28 \pm 3.33^{* * *}$ & $112.91 \pm 1.43^{* * *}$ & $5.51 \pm 0.19^{* * *}$ \\
\hline SXA-1 & $67.38 \pm 1.91^{* * *}$ & $66.53 \pm 2.68^{* * *}$ & $95.59 \pm 0.79^{* * *}$ & $5.04 \pm 0.21^{* * *}$ \\
\hline SXE-2 & $67.38 \pm 5.18^{*}$ & $97.02 \pm 4.10^{*}$ & $126.34 \pm 4.21^{*}$ & $7.42 \pm 0.32^{*}$ \\
\hline SXA-2 & $69.23 \pm 5.91^{*}$ & $95.02 \pm 3.34^{*}$ & $123.31 \pm 3.78^{*}$ & $7.34 \pm 0.49^{*}$ \\
\hline SXE-3 & $40.65 \pm 4.16^{* *}$ & $94.21 \pm 2.43^{* *}$ & $120.29 \pm 2.91^{* *}$ & $7.09 \pm 0.31^{* *}$ \\
\hline SXA-3 & $42.46 \pm 4.15^{* * *}$ & $80.49 \pm 1.62^{* * *}$ & $114.23 \pm 1.28^{* * *}$ & $6.03 \pm 0.21^{* * *}$ \\
\hline
\end{tabular}

All values are expressed in mean \pm SEM,

${ }^{*} p<0.05,{ }^{* *} p<0.01$ and $* * * p<0.001$ test group vs. stress group.

\begin{tabular}{|c|c|c|c|}
\hline \multirow[t]{2}{*}{ Groups } & \multicolumn{3}{|c|}{ Paw edema (ml) } \\
\hline & $1 \mathrm{~h}$ & $24 \mathrm{~h}$ & $48 h$ \\
\hline Control & $0.08 \pm 0.006$ & $\begin{array}{c}0.17 \pm 0.08 \\
(52.94)\end{array}$ & $\begin{array}{c}0.14 \pm 0.007 \\
(42.85)\end{array}$ \\
\hline Standard & $0.081 \pm 0.010$ & $0.24 \pm 0.01$ & $0.16 \pm 0.043^{* *}$ \\
\hline SXE-1 & $0.062 \pm 0.009^{* * *}$ & $\begin{array}{c}0.16 \pm 0.008^{* * *} \\
(61.25)\end{array}$ & $\begin{array}{c}0.12 \pm 0.07^{\star * *} \\
(48.33)\end{array}$ \\
\hline SXA-1 & $0.07 \pm 0.010^{* * *}$ & $\begin{array}{c}0.19 \pm 0.01^{* * *} \\
(63.15)\end{array}$ & $\begin{array}{l}0.17 \pm 0.4^{* * *} \\
\quad(58.82)\end{array}$ \\
\hline SXE-2 & $0.064 \pm 0.011^{* * *}$ & $\begin{array}{c}0.08 \pm 0.011^{* *} \\
(20.0)\end{array}$ & $\begin{array}{c}0.07 \pm 0.023^{* * *} \\
(8.57)\end{array}$ \\
\hline SXA-2 & $0.056 \pm 0.016^{* *}$ & $\begin{array}{c}0.086 \pm 0.012^{* * *} \\
(34.88)\end{array}$ & $\begin{array}{c}0.072 \pm 0.034^{* *} \\
(22.22)\end{array}$ \\
\hline SXE-3 & $0.056 \pm 0.014^{* * *}$ & $\begin{array}{c}0.12 \pm 0.01^{* * *} \\
(53.33)\end{array}$ & $\begin{array}{c}0.10 \pm 0.032^{* * *} \\
(44.0)\end{array}$ \\
\hline SXA-3 & $0.046 \pm 0.01^{* * *}$ & $\begin{array}{c}0.11 \pm 0.008^{* * *} \\
(58.18)\end{array}$ & $\begin{array}{c}0.098 \pm 0.04^{\star * *} \\
(53.06)\end{array}$ \\
\hline
\end{tabular}

Values are expressed in mean \pm SEM, values in parentheses have indicated percentage increase in respect to $1 \mathrm{~h} . * * p<0.01$ and $* * * p<0.001$ test groups vs. control group.

$34.88 \%$ respectively) increase in paw volume was found at $24 \mathrm{~h}$ as compare to at $1 \mathrm{~h}$, which was less than control animals (Table 3). This shows the maximum degree of immune system mediated hypersensitivity with fruit extracts compared to root extracts and standard drugs.

\section{Carbon clearance test}

SXE-1 (0.877 \pm 0.01$),$ SXA- 1 (0.748 \pm 0.02$)$, SXE-2 $(0.638 \pm 0.01)$ and SXA-2 $(0.796 \pm 0.02)$ significantly decreased carbon clearance, when compared to Control mean time $0.574 \pm 0.01$ (Table 4).

\section{$\mathrm{CCl}_{4}$ induced oxidative stress}

$\mathrm{CCl}_{4}$ treatment significantly increases in levels of SGOT, SGPT, bilirubin, cholesterol, but decrease in HDL when

\begin{tabular}{|c|c|}
\hline \multicolumn{2}{|c|}{ Table 4: Effect of the tested extracts on carbon } \\
clearance assay.
\end{tabular}

All the values are expressed in mean mean \pm SEM

$* * p<0.01$ and $* * * p<0.001$, test group vs. control group.

compared to control animals. These levels were restored by SXE-1 and SXA-1. Result of SXE-1 was better than standard (Table 5).

\section{Histopathological studies}

Results supports by histopathological study. Normal control group showed normal hepatic globular structure, central vein and portal tract and kuffer cells. Whereas in carbon tetrachloride treated group hepatic globular architecture is normal but hepatic cells have fatty degeneration like ballooning of hepatocytes, fatty cyst and infiltration of lymphocytes and proliferation of kuffer cells. Liver sinusoids are congested. The Group treated with ethanol extract of fruit has normal hepatic globular architecture and very few areas shown with lymphocytic infiltration. Majority of hepatocytes were normal (Figure 1A, 1B, 1C and 1D). In Standard drug treated group; the hepatic globular architecture is almost normal. Few fatty cells and some cells have shown hyaline and cytoplasm.

\section{Estimation of solasodine in S. xanthocarpum}

HPLC analysis has shown $0.894 \%, 1.146 \%, 0.643 \%$ and $0.620 \%$ of solasodine present in the SXE-1, SXA-1, 


\begin{tabular}{|c|c|c|c|c|c|c|c|}
\hline Group & $\begin{array}{l}\text { SGPT } \\
\text { (IU/L) }\end{array}$ & $\begin{array}{l}\text { SGOT } \\
\text { (IU/L) }\end{array}$ & $\begin{array}{l}\text { Total bilirubin } \\
\text { (mg/dl) }\end{array}$ & $\begin{array}{c}\text { Direct bilirubin } \\
(\mathrm{mg} / \mathrm{dl})\end{array}$ & $\begin{array}{c}\text { Total } \\
\text { cholesterol } \\
\text { (mg/dl) }\end{array}$ & $\begin{array}{c}\text { HDL } \\
\text { (mg/dl) }\end{array}$ & $\begin{array}{c}\text { Alkaline } \\
\text { phosphate } \\
\text { (IU/L) }\end{array}$ \\
\hline Control & $46.81 \pm 1.65$ & $95.66 \pm 0.66$ & $0.896 \pm 0.054$ & $0.174 \pm 0.010$ & $103.55 \pm 0.438$ & $46.76 \pm 0.274$ & $121.826 \pm 1.909$ \\
\hline $\mathrm{CCl}_{4}$ treated & $284.58 \pm 21.05$ & $523.22 \pm 15.95$ & $4.259 \pm 0.095$ & $1.587 \pm 0.08$ & $164.84 \pm 1.815$ & $26.81 \pm 0.36$ & $250.591 \pm 1.778$ \\
\hline SXE-1 & $62.58 \pm 1.69^{* * *}$ & $131.0 \pm 0.95^{\star * *}$ & $1.256 \pm 0.112^{* \star *}$ & $0.40 \pm 0.028^{* * *}$ & $117.24 \pm 0.695^{* * *}$ & $44.31 \pm 0.361^{\text {*** }}$ & $80.635 \pm 0.92^{\text {***}}$ \\
\hline SXA-1 & $208.11 \pm 6.54^{* * *}$ & $361.49 \pm 4.89^{* * *}$ & $3.051 \pm 0.068^{* * *}$ & $0.841 \pm 0.028^{* * *}$ & $154.06 \pm 2.71^{\text {*** }}$ & $31.23 \pm 0.416^{\star \star *}$ & $196.456 \pm 1.554^{* * *}$ \\
\hline Standard & $91.03 \pm 1.30^{* * *}$ & $130.76 \pm 1.51^{* * *}$ & $1.535 \pm 0.068^{* * *}$ & $0.544 \pm 0.023^{* * *}$ & $120.63 \pm 0.69^{* * *}$ & $40.77 \pm 0.53^{* * *}$ & $89.804 \pm 0.987^{* * *}$ \\
\hline
\end{tabular}
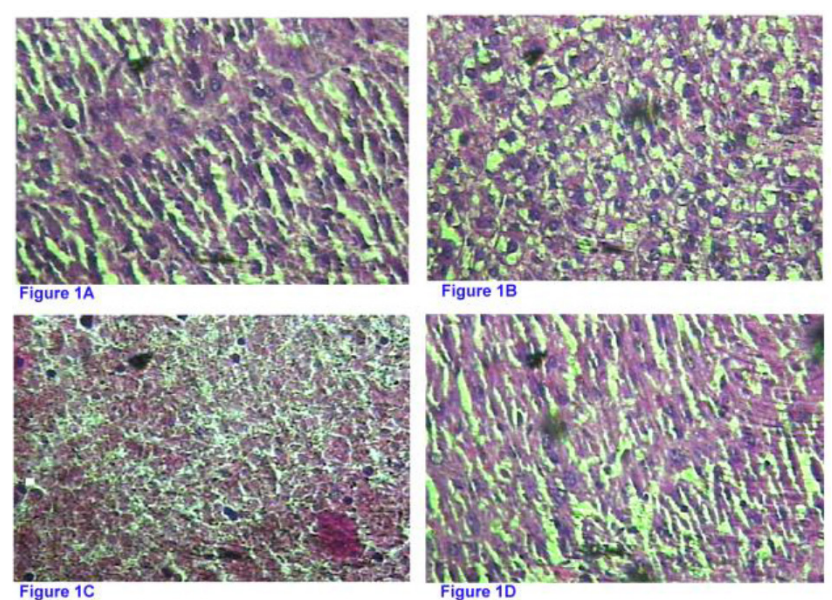

Figure 1A: Normal Control (-Ve Control); Hepatic Globular Structure, Central Vein, Portal Tract and Kuffer Cells Are Normal.

Figure 1B: Carbon tetrachloride treated group (+ve control); hepatic globular architecture is normal, hepatic cells have fatty degeneration like ballooning of hepatocytes, fatty cyst, and infiltration of lymphocytes and proliferation of kuffer cells. Liver sinusoids are congested.

Figure 1C: sxe-1 treated group; the hepatic globular architecture is normal. Very few areas are with lymphocytic infiltration. Majority of hepatocytes are normal.

Figure 1D: SXA-1 treated group; the hepatic globular architecture is normal with some fatty changes. A few areas are with lymphocytic infiltration. Majority of hepatocytes are normal.

SXE-2 and SXA-2 respectively (Table 6; Figure 2, 3A and $3 \mathrm{~B})$.

\section{DISCUSSION}

To detect the presence of various phytoconstituents in formulations as well as in raw materials phytochemical investigations were performed. The tests were performed on alcohol and water, extract. It has conforms the presence of alkaloids, flavonoids, steroids and saponins.

$200 \mathrm{mg} / \mathrm{kg}$ body weight $\left(1 / 10^{\text {th }}\right.$ of $\left.\mathrm{ALD}_{50}\right)$ dose was selected for in-vivo immunomodulatory study by Acute Toxicity Study (ALD50).

\begin{tabular}{|c|c|c|c|}
\hline \multirow{4}{*}{ Table 6: Content of solasodine in S. xanthocarpum } \\
Extract.
\end{tabular}

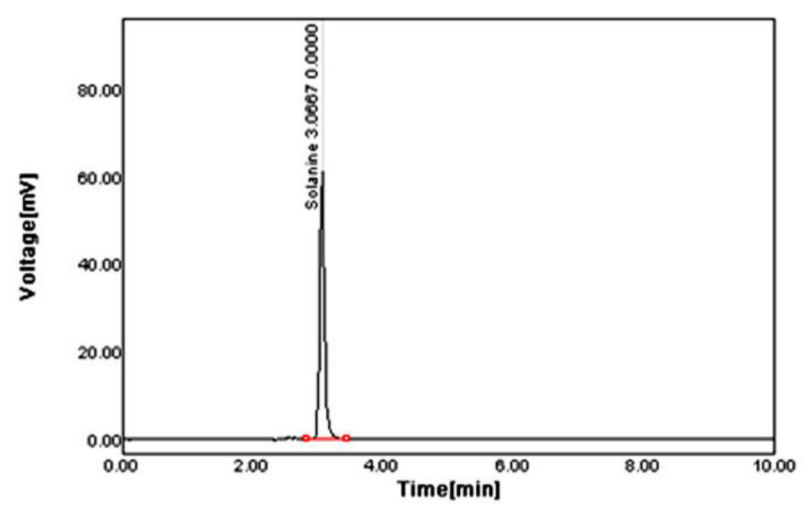

Figure 2: RP-HPLC chromatograph of Solasodine.

Biochemical parameters and hematological parameters are the index of immune system, imbalance of those parameters may disturb immune system. Our present study investigated that stress alters normal biochemical and hematological parameters, which may disturb immune system. ${ }^{22}$ The adoptive reaction enables the body to heighten its power of resistance towards stresses and to adopt external conditions. Pretreatment with Withania somnifera, SXE-1 and SXA-1 enhanced swimming survival time, when compared with stress control group in cold water swim stress. Present study revealed that stress causes alteration of normal biochemical parameters as well as change in vital organ weight and blood 

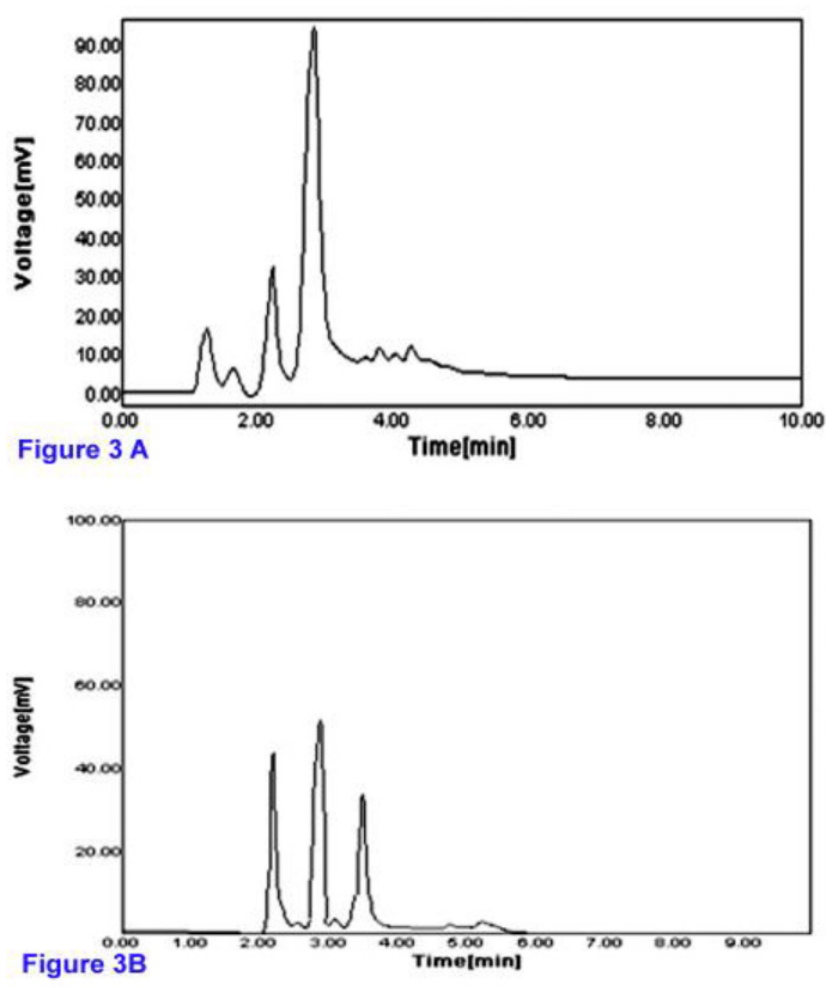

Figure 3A: RP HPLC chromatograms of solasodine in S. xanthocarpum ethanol fruit extract (SXE-1). Figure 3B: RP HPLC chromatograms of solasodine in S. xanthocarpum aqueous fruit extract (SXA-1).

cell count. The biochemical parameters like glucose, cholesterol, triglycerides were increased in stress control group but these parameters recovered significantly in SXE-1 and SXA-1 treated groups. Increased blood cell count in stress control group was also significantly decreased in the entire treated group except SXE-2 and SXA-2 treated.

Whereas, aqueous and ethanol extract of Solanum xanthocarpum fruits reported for protection of experimental animal against Cyclophosphamide induced immunosuppression. ${ }^{23-24}$

Modification of immune functions by pharmacological agents is emerging as a major area of therapies in those cases where undesired immunosuppression is the result of therapy. Such efforts were previously being carried out by using gluco corticoid in combination with cytotoxic drugs like cyclophosphomide. In contrast, desired immunostimulation (i.e. hyper-reactivity) is a common side effect with drugs like quinine, salicylate etc. In delayed type hypersensitivity model i.e. type T lymphocytes and activated macrophage mediated reaction, sensitize animals, when challenges with same allergens, result in a significant increase in paw edema when compared with control. Delayed type hypersensitivity also dem- onstrated that SXE-1 and SXA-1 as immunostimulant. Enhanced phagocytic activity of macrophages is evaluated by the rate of elimination of exogenously administered antigen such as carbon particles. In addition, in-vivo assay macrophages probably secrete a number of cytokines which in turn stimulate other immunocytes. This may give defense ability to counter the infectious stress to the host. ${ }^{19}$ Hepatic injury induced by $\mathrm{CCl}_{4}$ is due to its conversion into highly reactive radical trichloromethyl radical, which further react with oxygen to give trichloromethylperoxy radical. Cytochrome $\mathrm{P}^{450} 2 \mathrm{EI}$ is the enzyme responsible for this conversion which is a main culprit for hepatotoxicity. ${ }^{25}$ Trichloromethyl peroxy radical forms covalent bond with sulahydryl group of various membrane molecules like glutathione, protein thiol, lipid or unsaturated lipid. This covalent binding of free radical with the cellular macromolecule is considered the initial step in chain of events which leads to lipid peroxidation. ${ }^{25}$ This result in the release of marker enzymes like SGPT, SGOT, ALP etc. in addition billiary excretion of bilirubin level are raised and HDL level are decreased. Since GSH involve in the scavenging of highly reactive free radicals, liver damage is not seen until the significant depletion of GSH level. Therefore decreased level of GSH levels are observed in liver tissue. ${ }^{26}$

The two extracts SXA-1 and SXE-1 were further subjected for screening of hepatoprotective activity to find any possible correlation between immunostimulant and hepato-protective properties. Toxic liver injury produced by drugs and chemicals may virtually mimic any form of naturally occurring liver disease. Drugs like carbon tetrachloride or one of its metabolites is either directly toxic to the liver or it lowers the host immune defense mechanism. ${ }^{27-28}$

The observations in present study established the traditional claim and thus $S$. xanthocarpum could be a potent immunomodulatory agent for use in future. In our present study we conclude that aqueous and ethanol extract of Solanum xanthocarpum fruit have significant the immunostimulant potential. Whereas, aqueous and ethanol extract of root does not have immunostimulant potential.

In addition, aqueous and ethanol extract of Solanum xanthocarpum fruit are having significant hepatoprotective activity which may be attributed to the immunostimulant property. . Further the HPLC analysis of S. xanthocarpum revealed the presence of $1.146 \%$ and $0.894 \%$ solasodine in aqueous and ethanol extracts of S. xanthocarpum fruit respectively. But, $0.643 \%$ and $0.620 \%$ estimated in ethanol and aqueous extracts of S. xanthocarpum root respectively 


\section{CONCLUSION}

The observations in present study established the traditional claim and thus $S$. xanthocarpum could be a potent immunomodulatory agent for use in future. In our present study we conclude that aqueous and ethanol extract of Solanum xanthocarpum fruit have significant the immunostimulant potential. Whereas, aqueous and ethanol extract of root does not have immunostimulant potential. HPLC analysis of $S$. xanthocarpum revealed the presence of higher level of solasodine in aqueous and ethanol extracts of $S$. xanthocarpum fruit compared to ethanol and aqueous extracts of $S$. xanthocarpum root. Since solasodine is a lead constituent of the plant, hence solasodine may be responsible for the above immunostimulant property. However, further bioactivity guided phytochemical analysis in future could be reveal phytopharmacological relation of immunostimulant property and solasodine.

\section{ACKNOWLEDGEMENT}

Authors are thankful to Management, technical, nontechnical, account and administrative staffs of BRNSSContract Research Center, B. R. Nahata College of Pharmacy, Mandsaur-458001, Madhya Pradesh, India for their constant support during M. Pharm thesis work of Dr. Ravindra Kumar Pandey. Authors are also thankful to management, Principal and the other technical, non-technical, account and administrative staffs of Columbia Institute of Pharmacy, Raipur-492001, Chhattisgarh, India for providing their constant support for successful compilation of this work.

\section{CONFLICT OF INTEREST}

The authors declare no conflict of interest.

\section{ABBREVIATIONS}

SXE-1: Ethanol extracts of $S$. xanthocarpum fruit; SXA1: Aqueous extracts of $S$. xanthocarpum fruit; SXE-2: Ethanol extracts of S. xanthocarpum root; SXA-2: Aqueous extracts of $S$. xanthocarpum root; SXE-3: Ethanol extracts of $S$. xanthocarpum whole plant; SXA-3: Aqueous extracts of $S$. xanthocarpum whole plant; SGOT: Serum glutamic-oxaloacetic transaminase; SGPT: Serum glutamic pyruvic transaminase; $\mathbf{C C l}_{4}$ : Carbon tetrachloride; HPLC: High-performance liquid chromatography.

\section{REFERENCES}

1. Sharififar F, Pournourmohammadi S, Arabnejad M. Immunomodulatory activity of aqueous extract of Achillea wilhelmsii C. Koch in mice. Indian Journal of Experimental Biology. 2009;47(8):668-71.

2. Atal CK, Sharma ML, Kaul A, Khajauria A. Immunomodulating agents of plant origin. I: Preliminary screening. Journal of Ethnopharmacology. 1986;18(2):133-41.

3. Anonymous. The Wealth of India - A Directory of Indian Raw Materials and Industrial products, first supplement series, Vol.-5, R-Z, The National Institute of Science Communication and Information Resources-CSIR, New Delhi, India. 2004;11.

4. Kumar N, Prakash D, Kumar P. Wound healing activity of Solanum xanthocarpum Schrad. and Wendl. Fruits. Indian Journal of Natural Products and Resources. 2010;1(4):470-75.

5. Jitin R. An Ethnobotanical Study of Medicinal Plants in Taindol Village, District Jhansi, Region of Bundelkhand, Uttar Pradesh, India. Journal of Medicinal Plants Studies. 2013;1(5):59-71.

6. Singh OM, Singh TP. Phytochemistry of Solanum xanthocarpum: an amazing traditional healer. Journal of Scientific and Industrial Research. 2010;69:73240.

7. Parmar S, Gangwal A, Sheth N. Solanum xanthocarpum (Yellow Berried Night Shade): A review. Der Pharmacia Lettre. 2010;2(4):373-83.

8. Kiritikar KR, Basu BD. Indian Medicinal Plants. $2^{\text {nd }}$ ed., Bishen Singh Mahendra Pal Singh, Dehradun, India. 1935;3:1759-62.

9. Chopra RN, Nayar SL, Chopra IC. Glossary of Indian Medicinal Plants, National Institute of Science Communication and Information ResourcesCSIR, $6^{\text {th }}$ reprint, New Delhi, India. 2002;42-219.

10. Saived IZ. Fruits of Solanum xanthocarpum. The Proceedings of the Indian Academy of Sciences series. 1963;255-60.

11. Jain SP, Puri HS. Ethno medicinal plants of Jaunsar - Bawar Hills. Journal of Ethnopharmacology. 1984;12(2):213-22.

12. Kurian JC. Plants that Heal. Oriental Watchman Publishing House, $5^{\text {th }}$ ed, Pune, India. 2003;260-96.

13. Rahman MT, Ahmed M, Alimuzzaman M, Shilpi JA. Antinociceptive activity of the aerial parts of Solanum xanthocarpum. Journal of Ethnopharmacology. 2003;74(1-2):119-21.

14. Khandelwal KR. Practical pharmacognosy techniques and experiments. 18th ed. Nirali Prakashan: Pune, India. 2007;7-168.

15. Veerarghavan P. Acute Toxic Class Method (OECD Guideline No. 423, Annexure-2d). Committee for the Purpose of control and supervision of Experiments on Animals (CPCSEA), Animal Welfare Division, Government of India, Chennai, India, Letter dated $19^{\text {th }}$ September, 2001.

16. Bhargava KP, Singh N. Anti-stress activity of Ocimum sanctum (Linn). Indian Journal of Medical Research. 1991;73:433-51.

17. Goyal RK, Patel NM. Practical Anatomy and Physiology. $6^{\text {th }}$ ed, B.S Shah Prakashan, Ahmedabad, India. 2013;19-179.

18. Agarwal R, Diwanay S, Patki P, Patwardhan B. Studies on immunomodulatory activity of Withania somnifera (Aswgandha) extracts in experimental immune inflammation. Journal of Ethnopharmacology. 1999;67(1):27-35.

19. Ponkshe CA, Indap MM. In-vivo and in-vitro evaluation for immunomodulatory activity of three marine animal extracts with reference to phagocytosis. Indian Journal of Experimental Biology. 2002;40:1399-1402.

20. King J. Practical Clinical Enzymology. Van Nostrand Company Limited, London. 1965;66-309.

21. Shanmugasundaram $P$, Venkataraman $S$. Hepatoprotective and antioxidant effects of Hygrophil aauriculata (K. Schum) Heine Acanthaceae root extract. Journal of Ethnopharmacology. 2006;104(1-2):124-8.

22. Suljevic D, Jamak A, Alijagic A, Focak M, Mehinovic L. Link between Biochemical and Hematological Parameters and their Role as Pre-diagnostic Indicators of Acute Inflammation in Preschool Children. Albanian Journal of Medical and Health Sciences. 2016;47(2/3):28-37.

23. Rokeya S, Salma K, Devi K. Immunomodulatory effect of methanol extract of Solanum xanthocarpum fruits. International Journal of Pharma Sciences and Research. 2011;2(2):93-7.

24. Sultana R, Khanam S, Devi K. Evaluation of Immunomodulatory activity of Solanum xanthocarpum fruits aqueous extract. Der Pharmacia Lettre. 2011;3(1):247-53. 

Toxicology. 1999;37:603-7

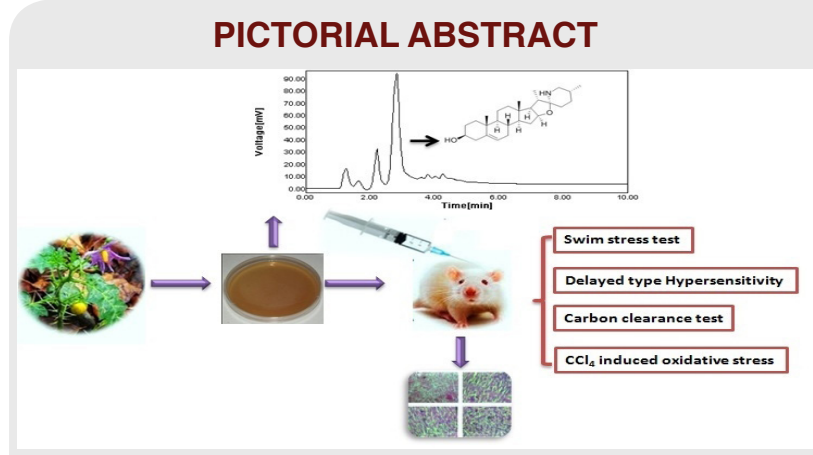

27. Poongothai K, Ponmurugan P, Ahmed KS, Kumar BS, Sheriff SA. Antihyperglycemic and antioxidant effects of Solanum xanthocarpum leaves (field grown and in vitro raised) extract on alloxan induced diabetic rats. Asian Pacific Journal of Tropical Medicine. 2011;4(10):778-85.

28. Harsh M. Text Book of Pathology. $7^{\text {th }}$ ed. Jaypee brothers Medical Publishers, New Delhi: India. 2015;262-319.

\section{SUMMARY}

- Solanum xanthocarpum used in the Indian traditional system of the medicine as an immunomodulatory agent.

- The fruit extracts (aqueous and ethanol) of S. xanthocarpum have exhibited higher degree of immunomodulatory effect compared to root and whole plant extract.

- The bioactive principal, Solasodaine contents more in fruit extracts compared to root and whole plant extract. Therefore, Solasodaine may responsible for immunomodulatory effects of the plants.

\section{About Authors}

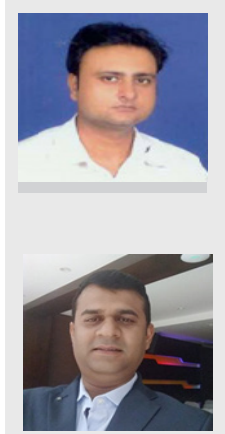

Dr. Ravindra Kumar Pandey (RKP),M.Pharm, Ph.D.Professor, Columbia Institute of Pharmacy (CIP), Raipur, was a main researcher for this work. Ravindra executed all experiments required for this work in Pharmacology lab, B. R. Nahata College of Pharmacy (BRNCP), Mandsaur-458001, Madhya Pradesh, India as per the instructions of supervisors and compiled the work as a manuscript in Columbia Institute of Pharmacy (CIP), Raipur-492001, Chhattisgarh, India. He also had done literature survey.

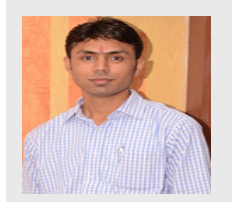

Dr. Avijeet Jain, M. Pharm, Ph.D. Professor \& Principal at Dr. Satayendra Kumar Memorial College of Pharmacy. He has participated in designed od overall pharmacognostical and phytochemical screening required for the thesis work and supervised the same. He also helps for compilation of research data in BRNCP.

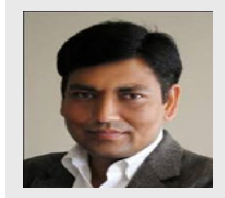

Dr. Vipin Bihari Gupta, M.Pharm, Ph.D. Ex. Professor \& Director, B. R. Nahata College of Pharmacy (BRNCP), Mandsaur. Vipin has supervised overall research activities and review the manuscript in BRNCP.

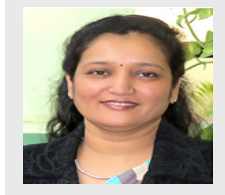

Dr. Anurekha Jain (AnJ), M.Pharma, Ph.D., Ex. Professor, B. R. Nahata College of Pharmacy (BRNCP), Mandsaur. Anurekha has designed phytochemical analysis required for this work and supervised respective work in BRNCP

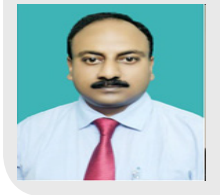

Dr. Lokesh Deb, M.Pharma, Ph.D. Scientist - C (Pharmacology),IBSD- Sikkim Centre (Department of Biotechnology, Govt. of India). Lokesh has designed and mentored overall project including pharmacological experiments in BRNCP. He also helps for writing the manuscript, finalized figures and tables with help of the team members and communicated the Manuscript from IBSD-SC.

Cite this article: Pandey RK, Shukla SS, Jain A, Jain A, Gupta VB, Deb L. Evaluation of Comparative Immunomodulatory Potential of Solanum xanthocarpum Root and Fruits on Experimental Animal. Indian J of Pharmaceutical Education and Research. 2018;52(4 Suppl 2):s237-s245. 